\title{
The Effect of Lipid Peroxide on the Lipid and Carbohydrate Metabolism in Rat Liver ${ }^{\dagger}$
}

\author{
Nobukazu Shibata, Toyosuke KInUmaki, Hiromichi OKUDA* \\ and Setsuro Fuj!* \\ Tokai Regional Fisheries Research Laboratory, Kachidoki-5, Chuo-ku, Tokyo \\ * Department of Enzyme Physiology, Institute for Enzyme Research, \\ School of Medicine, Tokushima University, Tokushima
}

Received January 16, 1973

\begin{abstract}
Feeding tests were carried out on rats to clarify the mechanisms of fatty liver formation induced by autoxidized methyl linoleate. Lipid peroxides prepared by autoxidation of highly purified methyl linoleate were given orally to rats. Triglyceride and glycogen contents in liver were determined and enzyme activities including triglyceride synthetase and $a$ glycerophosphate dehydrogenase were also examined. The following results were obtained. 1. Triglyceride accumulation in rat liver fed autoxidized methyl linoleate was observed. 2. Increase in triglyceride content in rat liver was soon followed by the decrease of hepatic glycogen. 3. When rats were starved prior to introduction of autoxidized methyl linoleate, hepatic triglyceride accumulation did not occur. 4. The activities of a-glycerophosphate dehydrogenase and triglyceride synthetase in liver, and those of glutamic oxalacetic transaminase and leucine aminopeptidase in plasma were practically similar among the rats of test groups fed fresh or autoxidized methyl linoleate and the control fed diet without methyl linoleate. 5 . The addition of $l$-carnitine which is a stimulator of fatty acid oxidation retarded the accumulation of the hepatic triglyceride mentioned above.
\end{abstract}

The acute and chronic toxicity of lipid peroxides is well known among many researchers. ${ }^{1,2)}$ The mechanism for the toxicity is still unclear, despite many reasonable hypotheses that have been propounded. Recently, many hypotheses associated with disease caused by autoxidized lipids were reported. And it was suggested that the peroxide in the autoxidized lipids was the factor influencing the development of atherosclerosis $^{3)}$ or aging ${ }^{4)}$ along with carcinogenesis. ${ }^{5)}$

J. G. Bergan et al. ${ }^{6 /}$ and the present authors ${ }^{7 /}$ have shown that the level of the substance derived from lipid peroxides appreciably increased in rat liver after oral administration of lipid peroxides. The effect of lipid peroxides on the activities of various enzymes has also been recognized by many reserchers. For example, it has been generally accepted that lipid peroxides deactivate $\mathrm{SH}$-enzymes ${ }^{8 ;}$

$\uparrow$ Contribution from the Tokai Regional Fisheries Research Laboratory B No. 572. and causes the damage of cytochromes" in rat liver. Furthermore, it has been reported that the hepatic injury caused by ethanol ${ }^{10)}$ or carbon tetrachloride ${ }^{11}$ had the tendency to stimulate lipid peroxidation on the membrane of microsome or mitochondria of the liver. These findings suggest that the lipid peroxides cause some important effects on the metabolic pathways in the liver.

In the present paper, the authors try to clarify the effects of lipid peroxides on the lipid and carbohydrate metabolism in rat liver.

\section{MATERIALS AND METHODS}

Lipid peroxide. The methyl linoleate used was prepared from safflower seed oil by methanolysis, followed by urea fractionation and vacuum distillation. The purity of the methyl linoleate was estimated to be more than $95 \%$ by gas chromatography. The methyl linoleate was placed in a Petri dish, autoxidized at $25^{\circ} \mathrm{C}$ with occasional agitation. The peroxide content in the autoxidized methyl linoleate samples. was determined by the modified Wheeler's method, ${ }^{12}$ ) 
and the peroxide values of these lipids are presented in each Table and Figure. These lipid doses were administered orally to rats by means of a stomach tube.

Experimental animal and diet. Male albino rats of Wistar King strain weighing $60 \sim 100 \mathrm{~g}$ were used in all experiments. A commercial stock ration (CA-1*) offered from Nippon Clea Co. Ltd. was used as the diet in the present experiments. The diet and water were fed ad libitum to rats.

Experimental procedure. The experiments performed were as follows:

Expts. 1) and 2). Fifteen rats (body weight, $60 \mathrm{~g}$ ), maintained on commercial stock diet, were divided into 3 groups. Group 1 received a single dose of $0.75 \mathrm{ml}$ of fresh methyl linoleate, group 2 a similar dose of autoxidized methyl linoleate while group 3 received none. After $18 \mathrm{hr}$ of administration of lipid, the rats were killed by drawing blood from the inferior vein cave under light ether anthesia and the liver was immediately removed. One part of the liver was homogenized in distilled water for chemical analyses, and the other in $0.25 \mathrm{M}$ sucrose solution for enzyme assay.

Expt. 3). Rats (body weight, $100 \mathrm{~g}$ ) of groups 1 and 2 were administered the same single dose of $1.2 \mathrm{~m}$ l of sample lipids as in Expts. 1) and 2). But the treated rats were killed after $1,2,4,10,18$ and $25 \mathrm{hr}$, respectively, under light ether anesthesia. Liver was homogenized in distilled water for determination of triglyceride and glycogen.

Expt. 4). The rats fed normal diet, weighing $100 \mathrm{~g}$ each, were divided into 2 groups, only one of which received $1.2 \mathrm{ml}$ of autoxidized methyl linoleate each. A group of prestarved rats was similarly treated with $1.2 \mathrm{ml}$ of autoxidized methyl linoleate. Starving was effected so as to remove all traces of food administered before $24 \mathrm{hr}$. Eighteen hr after administration, the rats were killed under light ether anesthesia. The livers were quickly removed and triglyceride and glycogen contents were determined.

Expt. 5). $\quad$-Carnitine solution $(50 \mathrm{mg} / \mathrm{ml})$ was intraperitoneally injected into another group of rats weighing $100 \mathrm{~g}$ each and previously fed $1.2 \mathrm{ml}$ of lipid peroxide. After $18 \mathrm{hr}$ of administration, the rats were killed and the livers were subjected to the determination of triglyceride and glycogen contents.

* Average analytical data of $\mathrm{CA}_{-1}$ are as follows $(\%)$; moisture 6.0 , protein 25.5 , fat 4.0 , fiber 4.0 , ash 7.0 , and soluble non- $\mathrm{N}$ substance 53.3 . The diet $(100 \mathrm{~g})$ contained the following vitamins; $A 10 \mathrm{IU}, \mathrm{D}_{3} 2 \mathrm{IU}$, E $25 \mu \mathrm{g}, \mathrm{B}_{2} 10 \mu \mathrm{g}, \mathrm{B}_{6} 4 \mu \mathrm{g}, \mathrm{B}_{1} 5.6 \mu \mathrm{g}, \mathrm{B}_{12} 0.02 \mu \mathrm{g}$, Ca-pantothenate $26 \mu \mathrm{g}$, Nicotinamide $44 \mu \mathrm{g}$, Folic acid $0.8 \mu \mathrm{g}$ and Choline chloride $400 \mu \mathrm{g} . \mathrm{Ca} / \mathrm{P}, \mathrm{Ca} /$ $\mathrm{Mg}$ and $\mathrm{K} / \mathrm{Na}$ are $1.28,7.20$ and 1.57 , respectively.
Enzyme assay. Glutamic oxalacetic transaminase activity was determined by Reitman-Frankel's method ${ }^{131}$ based on Friedman reaction. Leucine aminopeptidase activity was determined by Gordbarg's method. ${ }^{14}$ Triglyceride synthethase activity was determined by Hübscher's method. ${ }^{15}$ ) $a$-Glycerophosphate dehydrogenase activity was determined as follows: A mixture

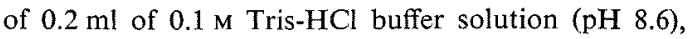
$0.2 \mathrm{ml}$ of $250 \mathrm{mM} \mathrm{MgCl}_{2}$ solution, $0.2 \mathrm{ml}$ of NAD solution $(50 \mathrm{mg} / \mathrm{ml}), 0.2 \mathrm{ml}$ of $0.5 \mathrm{M}$ sodium $a$-glycerophosphate solution and $0.2 \mathrm{ml}$ of $1 \mathrm{w} / \mathrm{v} \%$ liver homogenate solution was incubated at $37^{\circ} \mathrm{C}$ for $30 \mathrm{~min}$. At the end of incubation, $0.2 \mathrm{ml}$ of $10 \% \mathrm{Na}_{2} \mathrm{WO}_{4}$ solution and $1.4 \mathrm{ml}$ of acetone were added to the reaction mixture. The optical density of supernatant obtained by centrifuging was measured at $340 \mathrm{~m} \mu$.

Chemical analysis. Triglyceride content was determined by van Handel's method, ${ }^{16}$ ) cholesterol by modified Zak-Henly's method, ${ }^{17}$ free fatty acid by Dole's method. ${ }^{18}$ ) Glycogen estimation was made as follows: A liver sample $(0.5 \mathrm{~g})$ was added to $3 \mathrm{ml}$ of $30 \% \mathrm{KOH}$ solution in a centrifuge tube, and the mixture was heated in boiling water bath for $20 \mathrm{~min}$. After addition of $0.5 \mathrm{ml}$ of saturated $\mathrm{Na}_{2} \mathrm{SO}_{4}$ solution and then $4.0 \mathrm{ml}$ of $95 \%$ ethanol, the precipitate formed was collected after centrifuging. This precipitate was then dissolved in an arbitrary volume of water. The resulting solution, after neutralizing it with $4 \mathrm{~N} \mathrm{HCl}$ solution, was used for analysis by Anthron method. ${ }^{19}$ ) Glucose content was determined by the use of Glucostate. ${ }^{20}$ ) Protein content was determined by Lowry's method. ${ }^{21}$

\section{RESULTS}

Expt. 1) Changes in the contents of various components in liver and plasma of rats after administration of lipid peroxides

The content of hepatic triglyceride in rats fed lipid peroxides was significantly higher than that in the two sets of controls, one receiving fresh methyl linoleate and the other none (Table I). Cholesterol content also increased in the liver of rats when fed lipid peroxides. On the contrary, hepatic glycogen content decreased considerably after administration of lipid peroxide. However, no increase of glucose and free fatty acid in plasma were observed after administration of lipid perioxide, as shown in Table I.

\section{Expt. 2) Estimation of various enzyme acti-}


Table I. Levels of Various Components in Liver and Plasma of Rats

A peroxide value of autoxidized methyl linoleate was $2617 \mathrm{meq} / \mathrm{kg}$. Each value presents the mean \pm standard error. The numbers of determinations performed for each value quoted are in parentheses.

\begin{tabular}{|c|c|c|c|c|}
\hline \multirow{2}{*}{\multicolumn{2}{|c|}{ Components }} & \multirow[b]{2}{*}{ Control } & \multicolumn{2}{|c|}{ Methyl linoleate } \\
\hline & & & Fresh & Autoxidized \\
\hline \multicolumn{5}{|c|}{ 1. Liver } \\
\hline & Triglyceride (mg/g liver) & $5.9 \pm 0.9(5)$ & $6.2 \pm 0.5(5)$ & $10.0 \pm 1.9(5)^{a}$ \\
\hline & Glycogen (mg/g liver) & $35 \pm 7(4)$ & $41 \pm 8(5)$ & $8 \pm 6(5)^{a /}$ \\
\hline & Cholesterol (mg/g liver) & $2.8 \pm 0.2(5)$ & $3.1 \pm 0.2(5)$ & $3.6 \pm 0.3(5)^{a .1}$ \\
\hline \multicolumn{5}{|c|}{ 2. Plasma } \\
\hline & Glucose (mg/dl plasma) & $99 \pm 9(5)$ & $95 \pm 10(3)$ & $79 \pm 23(4)^{\mathrm{NS}}$ \\
\hline & Free fatty acid ( $\mu$ mole/liter) & $626 \pm 80(5)$ & $700 \pm 0(3)$ & $735 \pm 50(4)^{\mathrm{NS}}$ \\
\hline \multicolumn{5}{|c|}{$\begin{array}{l}\text { a) For differences between groups fed fresh and autoxidized methyl linoleate: } P<0.01 \text {; NS, not sig- } \\
\text { nificant. }\end{array}$} \\
\hline \multicolumn{5}{|c|}{$\begin{array}{c}\text { Table II. Effect of Lipid Peroxide on Various Enzyme } \\
\text { Activities of Liver and Plasma }\end{array}$} \\
\hline \multicolumn{5}{|c|}{ For the indication, see footnote in Table I. } \\
\hline & & & \multicolumn{2}{|c|}{ Methyl linoleate } \\
\hline & Enzymes & Control & Fresh & Autoxidized \\
\hline \multicolumn{5}{|c|}{ 1. Liver } \\
\hline & $\begin{array}{l}\text { Triglyceride synthetase (cpm/mg protein) } \\
\text { a-Glycerophosphate dehydrogenase }\end{array}$ & $1056 \pm 116(5)$ & $939 \pm 150(5)$ & $893 \pm 99(5)^{\mathrm{NS}}$ \\
\hline & $\left(\mathrm{OD}_{340} / \mathrm{mg}\right.$ protein) & $0.339 \pm 0.097(5)$ & $0.481 \pm 0.024(5)$ & $0.406 \pm 0.079(5)^{\mathrm{NS}}$ \\
\hline \multicolumn{5}{|c|}{ 2. Plasma } \\
\hline & $\begin{array}{l}\text { Glutamic oxalacetic transaminase } \\
\text { (Karmen unit) }\end{array}$ & $81 \pm 4(5)$ & $81 \pm 1(3)$ & $77 \pm 9(4)^{\mathrm{NS}}$ \\
\hline & $\begin{array}{l}\text { Leucine aminopeptidase } \\
\text { ( } \beta \text {-Napthylamine } \mu \mathrm{g} / 0.02 \mathrm{ml} \text { plasma) }\end{array}$ & $2.4 \pm 0.1(5)$ & $2.4 \pm 0.1(3)$ & $2.5 \pm 0.1(4)$ \\
\hline
\end{tabular}

vities in liver and plasma

The activities of various enzymes related to lipid synthesis were determined in order to clarify the cause of increase in hepatic triglyceride content. As shown in Table II, no appreciable activities of triglyceride synthetase and $a$-glycerophosphate dehydrogenase were observed in the liver of rats dosed with lipid peroxides. And also plasma glutamic oxalacetic transaminase and the leucine aminopeptidase activities did not change after administration of lipid peroxides.

Expt. 3) Chronological changes in triglyceride and glycogen contents of livers aftre administration of lipid peroxides

After $18 \mathrm{hr}$ of the administration of lipid peroxides, the hepatic triglyceride content reached to a quantity of 3 times more than that of normal (Fig. 1). On the contrary, hepatic glycogen concentration gradually decreased to about $20 \%$ of the original after $10 \mathrm{hr}$ of administration (Fig. 2). Therefore, although reverse relationship between hepatic triglyceride and glycogen contents was observed when lipid peroxides were given to the rats, the decrease in hepatic glycogen content initiated prior to the onset of the increase in hepatic triglyceride content as shown in Figs. 1 and 2.

Expt. 4) Effect of fasting on the change of hepatic triglyceride and glycogen in rats receiving lipid peroxides

This experiment was designed to elucidate the 


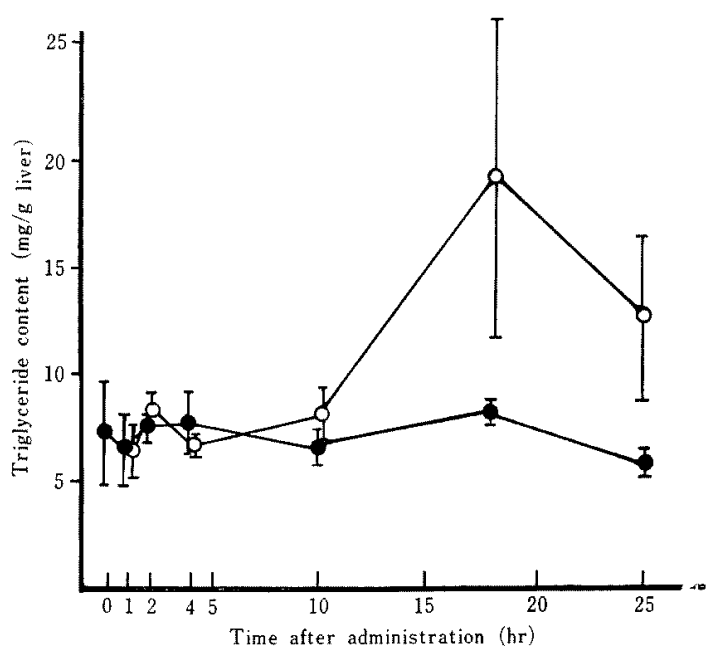

FIG. 1. Effect of Lipid Peroxide on Hepatic Triglyceride Content.

A peroxide value of autoxidized methyl linoleate was $2800 \mathrm{meq} / \mathrm{kg}$. Each point represents the mean \pm standard error obtained from 5 rats.

- - fresh methyl linoleate; - - , autoxidized methyl linoleate.

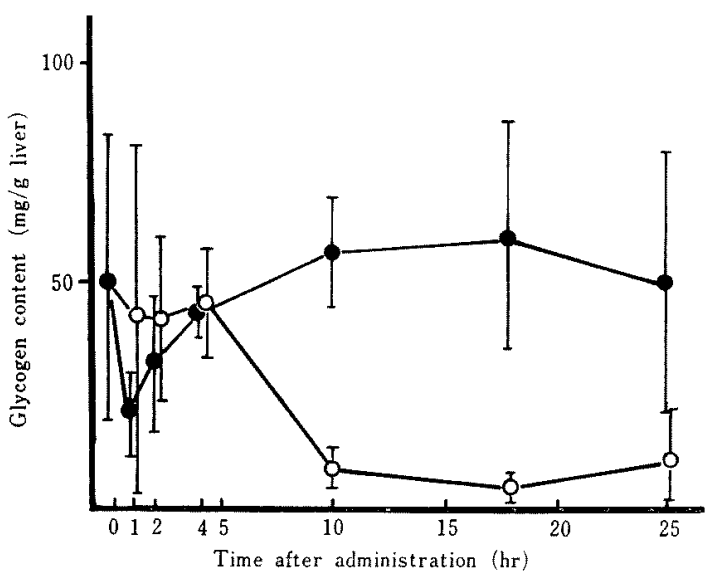

FIo. 2. Effect of Lipid Peroxide on Hepatic Glycogen Content.

For the indication, see footnote in Fig. 1.

relationship between the increase in hepatic triglyceride and the decrease in the glycogen content. The content of hepatic glycogen considerably decreased when rats were made to starve, as shown in Table III. When lipid peroxides were administered to the starved rats, no increase of hepatic triglyceride was observed.
Table III. Effect of Fasting on the Changes of Hepatic Triglyceride and Glycogen after Administration of Lipid Peroxide

A peroxide value of autoxidized methyl linoleate was $2500 \mathrm{meq} / \mathrm{kg}$. Each value presents the mean \pm standard error. The numbers of determination performed for each value quoted are in parentheses. For differences between group (A) and one of other groups (B, C and D):

\begin{tabular}{|c|c|c|}
\hline & $\begin{array}{l}\text { Lipid } \\
\text { peroxide }\end{array}$ & $\begin{array}{l}\text { Triglyceride } \\
\text { (mg/g liver) }(\mathrm{mg} / \mathrm{g} \text { liver) }\end{array}$ \\
\hline Normally fed & $\begin{array}{l}\text { (A) }-a ! \\
\text { (B) }+b !\end{array}$ & $\begin{array}{r}3.5 \pm 1.4(5) 41 \pm 13(5) \\
15.6 \pm 8.1(4)^{c)} 3 \pm 3(5)^{c}\end{array}$ \\
\hline Fasted & $\begin{array}{l}\text { (C) }-{ }^{a l} \\
\text { (D) }+{ }^{b}\end{array}$ & $\begin{array}{l}\mathrm{NS} \\
4.0 \pm 2.1(4) 8 \pm 5(4)^{\circ)} \\
5.1 \pm 2.7(4) 3 \pm 3(4)^{\circ)}\end{array}$ \\
\hline
\end{tabular}

a) No administration.

b) Administration.

c) $P<0.01 ; \mathrm{NS}$, not significant.

TABLE IV. EFFECT OF $l$-CARNITINE ON THE TRIGLYCERIDE ACCUMULATION AFTER Administration of Lipid Peroxide

For the indication, see footnote in Table III.

\begin{tabular}{|c|c|c|c|}
\hline & l-Carnitine & $\begin{array}{l}\text { Triglyceride } \\
\text { (mg/g liver) }\end{array}$ & $\begin{array}{c}\text { Glycogen } \\
\text { (mg/g liver) }\end{array}$ \\
\hline Control & (A) $-a$ ? & $8.0 \pm 1.0(5)$ & $64 \pm 9(5)$ \\
\hline Fed lipid & (B) $--^{a t}$ & $12.8 \pm 1.7(5)^{\circ}$ & $2 \pm 2(5)^{e}$ \\
\hline Peroxide & (C) $+t^{b}$ & $7.9 \pm 1.9(5)$ & $2 \pm 1(5)^{01}$ \\
\hline
\end{tabular}

a) No injection.

b) Injection.

Expt. 5) Effect of l-carnitine on the accumulation of hepatic triglyceride in rats receiving lipid peroxides

It is well known that $l$-carnitine stimulates fatty acid oxidation. ${ }^{22}$ However, it is not known whether $l$-carnitine prevents fatty liver formation produced by the introduction of chemical reagents or caused by dietary deficiencies. Therefore, an experiment was carried out to determine the effect of $l$-carnitine on the accumulation of hepatic triglyceride, caused by administration of lipid peroxides. As shown in Table IV, the result indicates that l-carnitine retarded the increase in hepatic triglyceride content, whereas it had no effect on the decline of hepatic glycogen. 


\section{DISCUSSION}

At present, the existence of many chemical agents which induce the accumulation of hepatic triglyceride is common knowledge. Some of them are ethanol, chloroform, carbon tetrachloride, orotic acid, ethionine, arsenicals and phosphorus. But the process of accumulation of hepatic triglyceride has not yet been clearly explained, in spite of the extensive studies that have been conducted by many researchers.

The present authors have already reported the accumulation of triglyceride in the liver of rat receiving methyl linoleate hydroperoxide. ${ }^{23}$ This accumulation was supposed to be due to the inhibition of the decomposition of hepatic triglyceride by deactivating lipase with substances derived from lipid peroxides which have been absorbed and transfered into the liver.

In our study, however, no inhibition of hepatic enzymes including lipase was observed, ${ }^{24)}$ though an oral administration of lipid peroxides caused the increase in hepatic triglyceride content and the decrease in glycogen content.

According to N. R. di Luzio et al., ${ }^{25)}$ the contemporary concepts of the source of increased content in hepatic triglyceride involve possibilities such as: 1) An impaired hepatic triglyceride secretory mechanism; 2) enhanced mobilization of free fatty acid from adipose tissue; 3 ) decreased intrahepatic oxidation of triglyceride; 4) enhanced triglyceride formation due either to an increased synthesis of fatty acid by the liver or by increased esterification of fatty acid to triglyceride. In addition to these, N. R. di Luzio et al. ${ }^{25}$ proposed another possibility on the origin of fatty liver: The oral administration of ethanol resulted in enhanced peroxidation of lipids, and the lipid peroxides thus produced caused the accumulation of hepatic triglyceride. They indicated this last possibility by the fact that the accumulation of hepatic triglyceride was significantly inhibited by the prior administration of antioxidants.
The present result indicates that the first, second and the fourth possibilities are remote, because no changes were observed in enzyme activities concerned with the decomposition of triglyceride to fatty acids and in plasma free fatty acid concentrations. The latter phenomenon also suggests that fat mobilization from adipose tissue did not occur. Triglyceride synthetase and $a$-glycerophosphate dehydrogenase participating in triglyceride syntheses were not appreciably activated by the administration of either fresh or autoxidized methyl linoleate when compared with the control. The activities of plasma glutamic oxalacetic transaminase and the leucine aminopeptidase did not alter after the administration of lipid peroxides. These facts suggest that lipid peroxides did not cause remarkable hepatic injury in this experimental condition.

From the results of our experiments mentioned above, the third or the last possibility is most proximate in the case of fatty liver caused by lipid peroxides. In the present experiments, by the administration of lipid peroxides, hepatic glycogen content decreased prior to the accumulation of triglyceride in the liver, and no increase of hepatic triglyceride was observed when the hepatic glycogen content was previously decreased during the period of starvation. In addition, the accumulation of hepatic triglyceride was prevented by the administration of l-carnitine which is a stimulant of fatty acid oxidation.

From those facts and the general concept that enzymes in TCA cycle system are deactivated by lipid peroxides, it can be suggested that glycolysis in liver was activated and then the metabolic products originated from the glycogen go to triglyceride synthesis rather than to TCA cycle. In all probabilities, further investigations will be necessary to elucidate these mechanism.

Recently, K. Sambe et al. ${ }^{26}$ observed that $D$-galactosamine caused the increase of the hepatic triglyceride and the decrease of the hepatic glycogen, just as in our experiment. However, they reported that the level of glucose and free fatty acid in serum were appre- 
ciably increased and serum glutamic pyruvate transaminase level also increased after the administration of the D-galactosamine. The latter phenomena are different from those in our experiments, which showed no change in glucose and free fatty acid level in plasma and also non-stimulation in the activity of triglyceride synthetase or $a$-glycerophosphate dehydrogenase. Therefore, it seems from these facts that lipid peroxides play a different role from D-galactosamine in the process of formation of triglyceride.

\section{REFERENCES}

1) "Lipids and Their Oxidation," ed. by H.W. Schultz, The AVI Publ. Co. Inc., Westport (1961).

2) S. G. Moss and H.S. Olcott, Proc. Soc. Exptl. Bio. Med., 124, 483 (1967).

3) I. Nishigaki, T. Osawa and K. Yagi, Vitamins (Japan), 38, 359 (1968).

4) M. Yoshikawa and S. Hirai, J. Gerontol, 22, 162 (1967).

5) K. Fukuzumi and T. Takagi, Yukagaku, 10, 643 (1961).

6) J. G. Bergan and H. H. Draper, Lipid, 5, 976 (1970).

7) T. Kinumaki, N. Shibata and K. Arai, Vitamins (Japan), 35, 188 (1967).

8) C. Little and P. J. O'Brien, Biochem. J., 106, 419 (1968).

9) R. C. Mcknight and F. E. Hunter, J. Biol. Chem.,
241, 2757 (1966).

10) N. R. di Luzio and A. D. Hartman, Fed. Proc., 26, 1436 (1967).

11) T. F. Salter and B. C. Sawyer, Biochem. J., 123, 823 (1971).

12) H. B. Knight and D. Swern, J. Am. Oil Chemists Soc., 26, 366 (1949).

13) S. Reitman and S. Frankel, Am. J. Clin. Path., 28, 56 (1957).

14) J. A. Goldbarg, ibid., 32, 571 (1959).

15) D. N. Brindley and G. Hünbsher, Biochem. Biophys. Acta, 106, 495 (1965).

16) E. Van Handel and D. B. Zilversmit, J. Lab. Clin. Med, 50, 152 (1957).

17) H. Yoshikawa and M. Kitamura, Igaku no Ayumi, 33, 375 (1960).

18) V. P. Dole and H. Meinertz, J. Biol. Chem., 235, 2595 (1960).

19) D. L. Morris, Science, 107, 254 (1948).

20) Z. P. Cawly, F. E. Spear and R. Kendall, Am. J. Clin. Path., 32, 375 (1959).

21) O. H. Lowry, N. J. Rosebrough, A. L. Farr and R. J. Randall, J. Biol. Chem., 193, 265 (1951).

22) I. B. Fritz, "Advance in Lipid Reserch," Vol. 1, ed. by R. Paatetti and D. Kritchevsky, Academic Press Inc., New York, N.Y., 1963, p. 285.

23) T. Kinumaki, Bull. Jap. Soc. Sci. Fish., 36, 854 (1970).

24) K. Yamakawa, N. Shibata, T. Kinumaki, H. Okuda and S. Fujii, Vitamins (Japan.), 46, 145 (1972).

25) N. R. di Luzio and A. D. Hartman, Fed. Proc., 26, 1436 (1967).

26) K. Sambe, M. Tsuchiya, K. Kamegaya, M. Oda and I. Okazaki, Kanzo, 13, 85 (1972). 